\title{
Analysis of modern approaches to improve the efficiency of blackout accident management at nuclear power plants
}

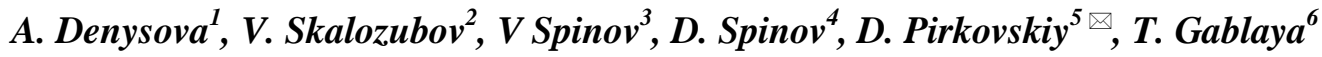 \\ 1,2,3,4,5,6 Odessa National Polytechnic University, 1 Shevchenko Ave., Odessa, 65044, Ukraine \\ $\triangle$ e-mail: ${ }^{5}$ pirkovskiy@opu.ua
}

The paper analyzes the approaches to improve the efficiency of blackout accident management taking into account the lessons of the great accident at Fukushima Daiichi NPP in 2011. It is found that the afterheat removal passive systems by natural circulation through steam generators cannot provide conditions for adequate safety functions to remove heat from the reactor and maintain the required feedwater level in the steam generator during blackout accidents and multiple failures of safety-related systems. The application of alternative approaches using auxiliary feedwater steam generator driven pumps requires additional experiment-calculated operability / reliability qualification for a blackout accident and multiple failures of NPP safety-related systems. However, implementation of alternative SDEFP system requires in-depth qualification for the conditions of blackout accidents. Safety systems of passive heat removal from the steam generator (adequately to active safety electrical systems) cannot ensure safety functions on control of required feedwater level in the steam generator and heat removal from the reactor core during blackout accidents (at least 72 hours) and multifailure accidents. The system of the steam generator driven emergency feedwater pump can be the alternative solution to ensure safety functions on heat removal through the steam generator during blackout accidents. Additional study of efficiency of steam driven pumps at the experimental facilities that meet real-life criteria of hydrodynamic similarity is a necessary condition for implementation of system of the steam driven emergency feedwater pump. Application of an integrated approach to manage blackout accidents is reasonable. At the initial stage of accident with relatively high steam pressure in the steam generator it is required supply of feedwater by the steam driven emergency pump.

Key words: Nuclear power plants; Accident with power failure; Heat removal; Steam driven pumps

doi: https://doi.org/10.15673/ret.v55i4.1635

(c) The Author(s) 2019. This article is an open access publication

This work is licensed under the Creative Commons Attribution 4.0 International License (CC BY) http://creativecommons.org/licenses/by/4.0/

\section{Relevance}

Many researches and scientific and technical reports covers the analysis of the reasons, consequences and lessons of great accident at Fukushima-Daiichi NPP in 2011: TEPCO/operating organization, IAEA experts [1], stress tests of National safety regulatory inspectorates/commissions of the leading nuclear states, the largest design and production companies of nuclear power, independent scientific researches etc. The analytical review of these works can be found, for example, in $[2,3]$.

At the initial moment of accident, at Units 1, 2 and 3 BWRs were automatically stopped by earthquake recording signal (the other three power units were under repair). A flooding of the NPP site and the total loss of long power supply (blackout) were consequences of a tsunami. After certain time, electric pumps of the active safety systems (ASS) fail to fulfil safety function on reactor heat removal (ARPS) because of blackout. The toroidal bubbler condenser is the main passive safety system (PSS) of BWRs at 
Units $1-3$ of Fukushima-Daiichi NPP. However, this BWR PSS also could not fulfil required ARPS because of increasing pressure in reactors and containments. Therefore, the staff of Unit 1 made preventive ventilation of containment to decrease pressure and connect alternative low-pressure cooling systems. After this ventilation, there was a destructive explosion and highly radioactive material release. Ingress of hydrogen from the inert atmosphere of containment to external air environment is a possible cause of explosion. Different scenarios of severe accident progress at Units 2 and 3 were depended on efficiency of the staff actions to restore ARPS $[1,2]$. It was also not succeeded to prevent destructive steam-gas explosion at Unit 3. Loss of ARPS and/or ingress of hydrogen from the next damaged unit are possible causes of explosions in rooms of a spent fuel pool at Unit 4.

Actual Fukushima lessons concerning blackout accidents the followings:

- PSS have to fulfil safety functions for a long time, adequately to ASS;

- PSS have to meet requirements for seismic stability and other external extreme events, as well as the main NPP equipment.

These lessons define the fundamental adequacy principle of PSS and ASS to ensure critical safety functions during blackout accidents.

Taking into account Fukushima lessons, results of stress tests on safety review of nuclear power facilities (NPF) with different reactors have found appropriateness of development of the alternative afterheat removal passive systems (ARPS) for blackout accidents [3]. ARPS from the reactor containment (CARPS) are most developed. The representative overview of this development is provided, for example, in $[4,5]$. The primary function of CARPS is to keep pressure and temperature in containment below the safety limits for blackout accidents. To solve the specified problem the work [6] proposes CARPS using closed evaporating and condensing devices, lowtemperature annular two-phase thermosiphons (TTS). Because of transfer of the latent heat of steam generation of the intermediate coolant, TTS provides effective heat removal from containment to a terminal absorber. The evaporator of annular TTS is placed near to dome part of containment; the condenser is placed outside containment. The evaporator and the condenser are connected by transport steam and condensate pipelines (Figure 1).

As resulted from MELCOR 1.8.5 calculation, containment parameters do not reach design limits that threaten the containment integrity [6] during any of the postulated accidents. The worst (conservative) scenario - a complete steam line guillotine rupture at the exit from the steam generator (SG) and the main two-side steam outflow into containment - was chosen for the computer analysis. It provides the greatest containment pressure increase as at the initial stage of accident, and further. Residual energy releases of a nuclear core are discharged together with steam through the damaged SG into containment in the conditions of natural coolant circulation.

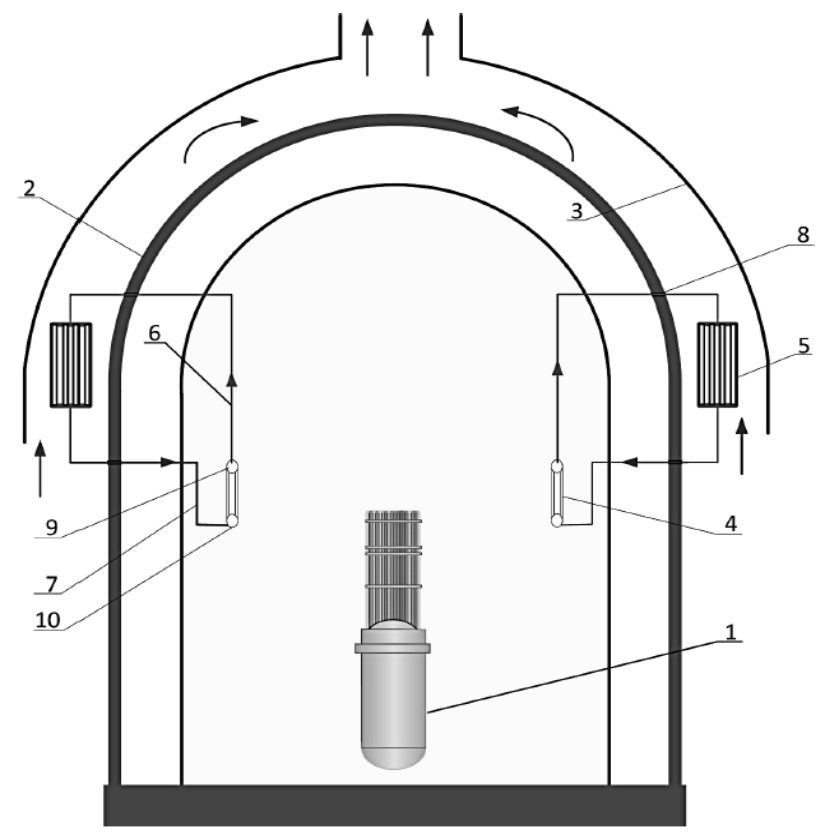

Figure 1 - The autonomous CARPS based on annular TTS: 1 -Reactor, 2 - Containment, 3-Air channel, 4-Evaporator, 5 -Condenser, 6-Steam pipeline, 7 -Condensate pipeline, 8 - Penetration, 9 -Collecting receiver, 10 -Dispensing receiver.

As to found results of computer modelling [6], to substantiate efficiency of CARPS with TTS at blackout it is required the followings:

1. Experimental verification of computing methods and means is needed to substantiate the design and technical parameters of CARPS with TTS. Especially it concerns the heat-transfer coefficients on an external surface $\left(100 \mathrm{~W} / \mathrm{m}^{2} / \mathrm{K}\right)$ and from an outer surface of a plate-condenser $\left(500 \mathrm{~W} / \mathrm{m}^{2} / \mathrm{K}\right)$ because of these coefficients determine directly the TTS sizes, quantity of plate-condensers, and the thermal power discharged by TTS.

2. Analysing heat hydrodynamic parameters of containment during an out-vessel stage of a severe accident it is necessary to consider essential effect of surface area and temperature of fusion. It is required the additional analysis of pressure and temperature of 
the containment steam-gas environment depending on these factors during severe accidents.

3. The work [6] determines accident of a double ended rupture of main steam lines in case of feedwater non-isolation of SG as the worst conditions for increasing pressure and temperature of the containment steam-gas environment. In case of such non-isolation the required level of boiler water in SG is keep by emergency and/or auxiliary feedwater pumps (EFWP/AFWP). In case of blackout these pumps fail and do not fulfil safety functions on keeping required level of the SG boiler water and heat removal from the reactor core.

Thus, to fulfil safety functions on keeping required level of feedwater in SG and heat removal from the reactor during blackout accidents, it is need to develop and implement alternative systems based on the adequacy principle of passive and design active safety systems.

\section{The analysis of afterheat removal passive systems through the steam generator}

Afterheat removal system through the secondary SG (SG ARPS) is one of the perspective ARPS for VVERs/PWRs. A basic function of SG ARPS is to ensure safety function on control of required level in SG (SF SG) during blackout accidents and heat removal from the reactor (SF HR).

The analysis of SG ARPS operated and designed allows drawing preliminary conclusions:

1. SG ARPS actually are auxiliary systems for active safety systems providing SF HR. Therefore, according to the IAEA experts, air-cooled SG ARPS provides heat removal from a reactor up to $2 \%$ of the rated power of the reactor. Such conditions may be sufficient to remove residual heat from the shutdown reactor (SF HR). However, it is needed to consider one of the main Fukushima lessons: modelling, analysing and emergency actions have to be developed for multifailure accidents (including improbable failures). If emergency protection of a reactor shutdown fails, SG ARPS does not provide SF HR.

Safety function on control of required water level in $\mathrm{SG}$ (SF SG) is also provided insufficiently for a long time (not less than 72 hours). Decrease in water level in SG can lead to damage of heat-exchanging SG pipes and to beyond design basis interloop-break accidents.

2. To ensure required natural circulation, the airor water-cooled SG ARPS heat-exchanging surface has to be placed at high altitude outside containment.
Such approach greatly reduces resistance of SG ARPS and containment to external extreme actions, as to the NPF main equipment.

Thus, the adequacy principle of PSS and ASS is not sufficiently provided during blackout and multifailure accidents.

Design and technical restrictions to ensure the adequacy principle for the SG ARPS and design ASS can be shown on the example of the simplified conservative heat hydraulic model of SG ARPS at NPF with VVER (Figure 2).

The heat hydraulic equations for SG ARPS can be presented in quasistationary approximation:

$$
\begin{aligned}
& G\left(i^{\prime \prime}-i^{\prime}\right)+C_{p} \cdot G \cdot \Delta T_{1}=\alpha F \Delta T_{2} \\
& \left(\rho-\rho_{v}\right) \cdot g H=\left(\frac{\xi_{v}}{\rho_{v} A_{v}^{2}}+\frac{\xi_{v}}{\rho_{l} A_{l}^{2}}\right) \cdot G^{2}
\end{aligned}
$$

where $G-$ is a SG ARPS flow, $i^{\prime \prime}, i^{\prime}-$ is a saturated steam and condensate enthalpy, respectively, $C_{p}$ - is the condensate specific heat capacity, $\Delta T_{1}$ - is a temperature difference of the saturated $\left(T_{s}\right)$ and cooled $\left(T_{k}\right)$ condensate, $\Delta T_{2}$ - is an average temperature difference between the circulating flow and environment $\left(T_{0}\right), \alpha-$ is a heat transfer coefficient between the circulating flow and environment [4], $F-$ is a heatexchange area of SG ARPS, $\rho_{l}, \rho_{v}-$ is liquid and steam density, respectively, $g$ - is acceleration of gravity, $H$ - is SG ARPS height, $\xi_{v}-$ is total drag coefficient for steam and liquid section, respectively [5], $A_{v}$, $A_{l}$ - is the average throat area of SG ARPS for steam and liquid section, respectively.

Then, conditions for ensuring the adequacy principle of the SG ARPS and EFWP follow from (1), (2):

$$
\begin{aligned}
& F \geq F_{\text {min }}=\frac{i^{\prime \prime}-i^{\prime}+C_{p} \cdot \Delta T_{1}}{\alpha \cdot \Delta T_{2}} \cdot G \\
& H \geq H_{\text {min }}=\frac{\frac{\xi_{v}}{\rho_{v} A_{v}^{2}}+\frac{\xi_{l}}{\rho_{l} A_{l}^{2}}}{\left(\rho_{l}-\rho_{v}\right) g} \cdot G^{2}
\end{aligned}
$$

Minimum values of the throat area of the condensed flow in natural circulation circuits can be estimated from conditions for lack of condensation water hammers [9]:

$$
F_{r}=\frac{G}{\rho \cdot A \sqrt{g}} \cdot\left(\frac{4 A}{\pi}\right)^{\frac{1}{4}}<1
$$

Condensation water hammers violate conditions for steady circulation in a SG ARPS circuit. 
Then, lower limit of the throat area of SG ARPS is from a condition (5):

$$
A_{H}=\sqrt[3]{\frac{4 \cdot G^{4}}{\pi \rho_{l}^{4} g^{2}}}
$$

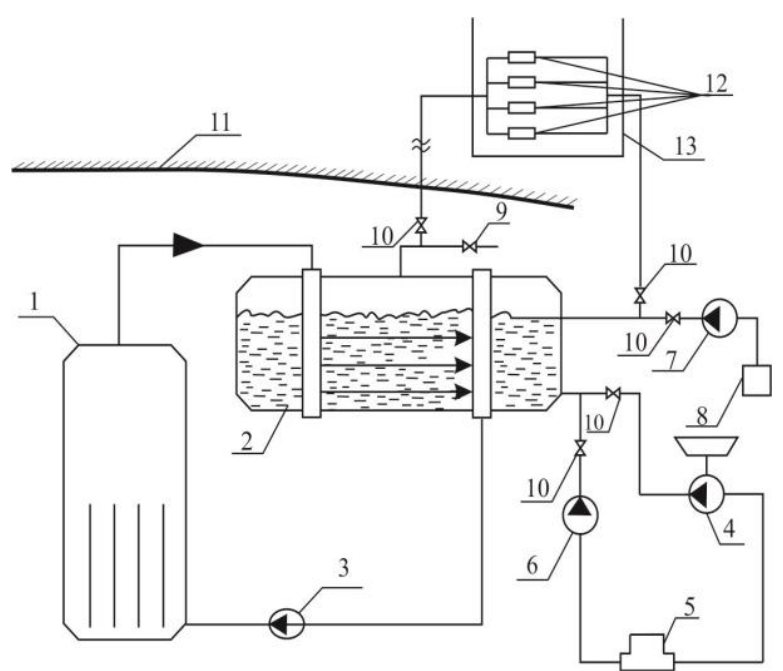

Figure 2 - Standard scheme of SG ARPS of VVER:

1 -Reactor, 2 -SG, 3 -Main circulation pump (MCP), 4 - Turbine feed pump (TFP), 5 - Deaerator, 6-AFWP, 7 -EFWP, 8 -EFWP water storage tank,

9 - Main steam isolation valve (MSIV), 10 - Stop valves, 11 -Containment, 12 -SG ARPS condensers, 13 - Water storage tank (for water-cooled SG ARPS condensers).

The upper limit of the throat area $\left(A_{B}\right)$ can be determined from condition that stresses $(\sigma)$ in metal of SG ARPS of the mass of M(A) under seismic effects do not exceed maximum stress $\sigma_{\text {мах }}[10,11]$ :

$$
\sigma\left[M\left(A_{B}\right), H_{0}, a_{c}\right] \leq \sigma_{\max }
$$

where $H_{0}-$ is the maximum height of SG ARPS above the ground, $a_{\mathrm{c}}-$ is a response of earthquake acceleration on site ground.

From the equation (3) it follows that for an oncethrough smooth pipe heat-exchange surface of SG ARPS under air heat removal, condensate temperature no more than $320 \mathrm{~K}$, and compensation of a EFWP flow (about $30 \mathrm{~kg} / \mathrm{s}$ ): $F_{\min } \geq 3.5 \cdot 10^{5} \mathrm{~m}^{2}$.

The problem of implementation and the large heat exchange area of SG ARPS can be solved by actions to increase intensity of external heat exchange (for example, external ribbing of a heat-exchange surface) and install compact modular heat exchangers (see Fig. 2). However, the hydraulic resistance of a circulation circuit of SG ARPS much increases in this case. According to a condition (4), it results in need to increase the general height of SG ARPS above containment surface by a few hundred meters. These leads to a great decrease in seismic stability (6b) and decrease in the general safety level against external extreme effects.

Under similar conditions and water heat removal, minimum area $F_{\text {min }}$ can be reduced by some orders due to an intensification of external heat exchange $(\alpha)$. However, in this case there are restrictions for the volume of the cooling water heat exchanger during the minimum operation time $\tau_{0}$ of SG ARPS for accident progress. Operability of safety systems (including passive systems) for at least 3 days $\left(\tau_{0}=25.92 \cdot 10^{4} \mathrm{~s}\right)$ is one of Fukushima lessons [1]. Thus, the water inventory in the SG ARPS heat exchanger has to be sufficient before full steam generation for a time at least $\tau_{0}$.

Let consider this problem also in the framework of the conservative heat hydrodynamic model consisting of a heat-exchange surface of the area $F$ submerged in the heat exchanger with a cooling water volume $V$ and initial temperature $T_{0}$.

The heat transfer equation in a cooling water volume:

$$
\begin{gathered}
V \rho_{l} \frac{\mathrm{d} T}{\mathrm{~d} t}=\alpha \cdot F\left(T_{s}-T\right) \\
T(t=0)=T_{0}
\end{gathered}
$$

where $T_{s}$ - is condensate saturation temperature in a circulation circuit of SG ARPS.

Then, the necessary a cooling water volume is from the decision (7), (8):

$$
V \geq V_{\min }=-\tau_{0} \frac{\alpha F}{\rho_{l}} \ln \cdot \frac{\left(T_{s}-T_{s_{0}}\right)}{\left(T_{s}-T_{0}\right)}
$$

where $T_{s 0}$ - is boiling temperature in volume of the SG ARPS heat exchanger.

Thus, the main restrictions for application of water cooled SG ARPS are connected with need of unrealistically large water volumes for each SG at considerable height above containment.

Therefore, search of alternative approaches to ensure safety functions on heat removal and control of SG level during blackout accidents and multifailure accidents of the safety related systems is an actual task.

\section{The alternative ensuring the adequacy principle of passive and active safety sys- tems at blackout}

The works of Professor Korolev A.V. provide the 
original technical solution using steam power to feed steam generators at NPP blackout [12]. Use of the steam generator driven emergency feedwater pump (SDEFP) is proposed to ensure the adequacy principle of PSS and design ASS (Figures 3 and 4).

The disk pump is chosen for reasons of its cavitation stability during the operation with large pressure differences. According to the researches, these pumps can reach a head of 5.0 MPa at one stage in the cavitation free mode. The main advantages of SDEFP as to SG ARPS to manage blackout accidents:

a) Possibility in principle of full compensation of EFWP failure to ensure SF HR and SF SG,

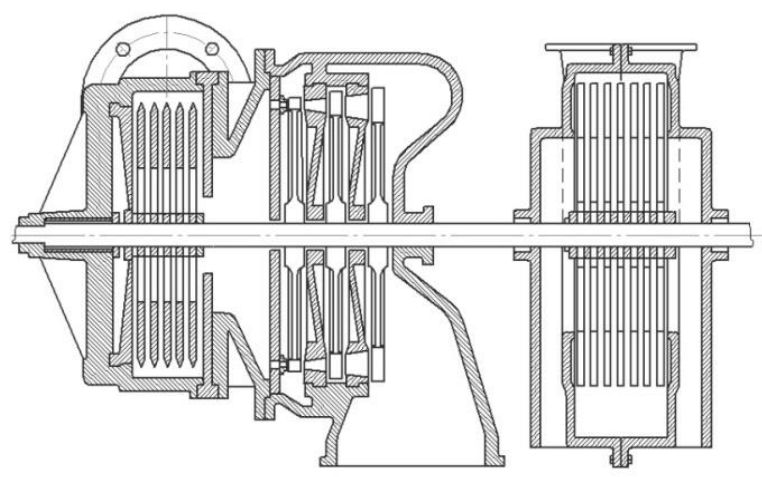

Figure 3 - The combined driven disk pump (SDEFP)

b) No need to place elements of safety systems at high altitude outside containment.

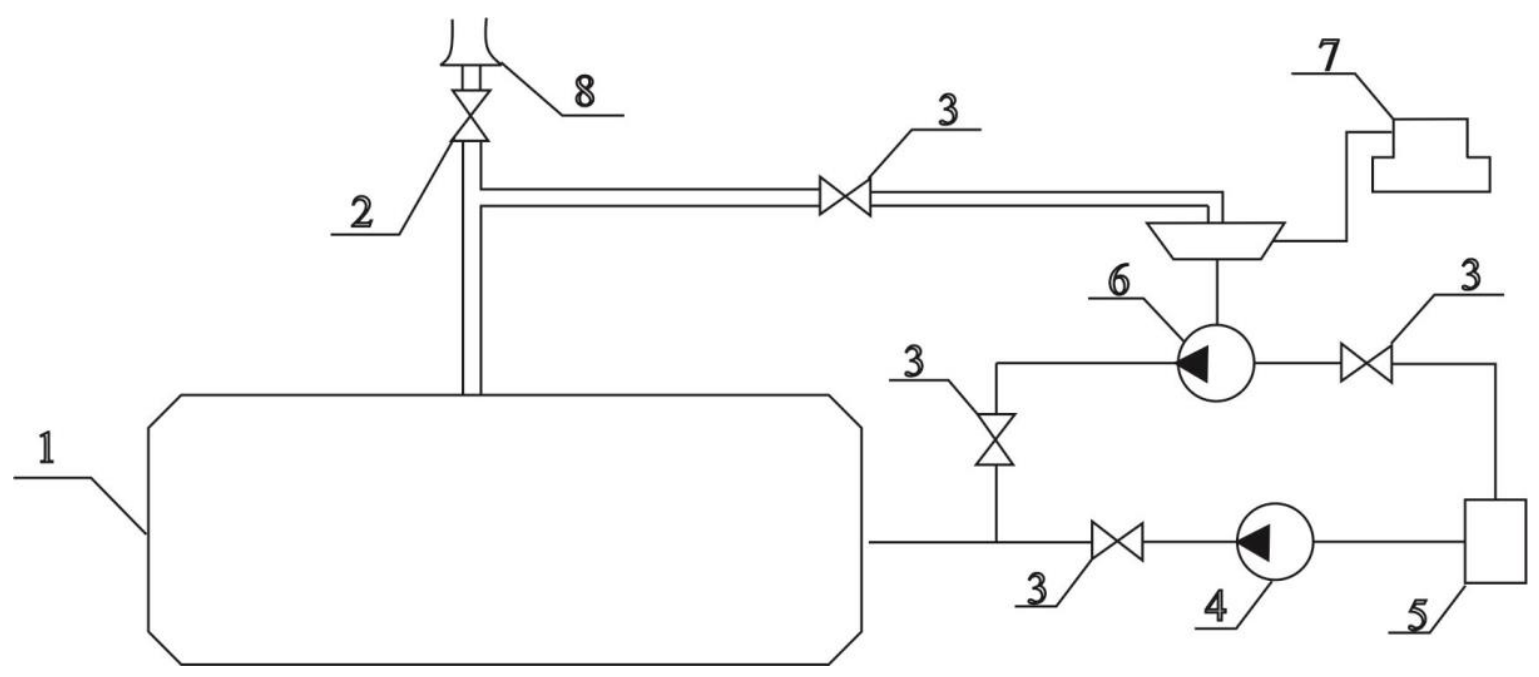

Figure 4-A key connection diagram of SG SDEFP at blackout accidents: $1-S G, 2-M S I V, 3$ - Stop valves, 4-EFWP, 5-hydraulic reservoirs of EFWP, 6-SDEFP, 7 -Deaerator, 8 -NPF turbine

However, implementation of alternative SDEFP system requires in-depth qualification for the conditions of blackout accidents. In particular, definition of conditions for steady operability/reliability of SDEFP system in the transitional and steady modes is necessary. These conditions can be defined as results of operational tests and/or experiments at the facilities meeting requirements of identity of criteria of hydrodynamic similarity [13].

\section{Main conclusions}

1. Safety systems of passive heat removal from the steam generator (adequately to active safety electrical systems) cannot ensure safety functions on control of required feedwater level in the steam generator and heat removal from the reactor core during blackout accidents (at least 72 hours) and multifailure acci- dents. Great design and technical restrictions as to overall dimensions to ensure adequacy of safety function are a main reason for this. Besides, placing heatexchange surfaces (as elements of safety systems) outside containment at high altitude from the ground reduces the general safety level of the power unit as to external extreme effects (earthquakes, tornados, hurricanes, etc.).

2. The system of the steam generator driven emergency feedwater pump can be the alternative solution to ensure safety functions on heat removal through the steam generator during blackout accidents. Main advantages of such approach:

- Fulfilment of safety functions on control of boiler water level in the steam generator and heat removal from the reactor core during at least 200 days/a safety system channel (if needed) adequately to emergency feedwater electric pumps; 
- Effective use of steam generated in the steam generator during accident without steam release into the turbine condenser and/or environment;

- No need of placing elements of safety systems at high altitude outside containment.

3. Additional study of efficiency of steam driven pumps at the experimental facilities that meet real-life criteria of hydrodynamic similarity is a necessary condition for implementation of system of the steam driven emergency feedwater pump.

4. Application of an integrated approach to manage blackout accidents is reasonable. At the initial stage of accident with relatively high steam pressure in the steam generator it is required supply of feedwater by the steam driven emergency pump. At the final stage of accident with relatively low pressure in the steam generator, it is required supply of feedwater by natural circulation of secondary afterheat removal passive system.

\section{References}

1. International Fact Finding Expert Mission of the Fukushima-Daiichi NPP Accident Following the Great East Japan Earthquake and Tsunami / IAEA Mission Report. IAEA, 2011, 160.

2. Skalozubov, V. I., Kljuchnikov, A. A., Vashhenko, V. N., Jarovoj, S. S. (2012) Analysis of the causes and consequences of the accident at Fukushima NPP as a factor in preventing severe accidents in hull reactors. Chornobyl, ISP NPP NASU, 280. (in Russian). ISBN: 978-966-02-6195-2.

3. Skalozubov, V. I., Oborsky, G. A., Kozlov, I. L. et al. (2013) A complex of methods for reassessing the nuclear power engineering safety in Ukraine, taking into account lessons of ecological disasters in Chernobyl and Fukushima. Astroprint, Odessa, 242. (in Russian). ISBN 978-966-190-824-5.

4. Bakhmetyev, A. M., Babin, V. A., Khizbullin, A. M. et al. (2007) Tasks of calculated experimental justification of residual heat removal system for new generation nuclear power plants. Proc. of the 5th International Scientific and Technical Conference "Safety Assurance of NPP with WWER", May 29 - June 1, 2007, Podolsk. Hydropress, 2, 303-308. (in Russian). ISBN 978-5-94883-074-2.
5. Naffaa, Kh. M., Dubkovsky, V. A. (2014) Classification of passive heat residual removal systems from reactors containments. Odeskyi Politechnichnyi Universytet. Pratsi, issue 1(43), 104-112. (in Russian). Doi: 10.15276/opu.1.43.2014.20.

6. Naffaa, Kh. M., Gerliga, V. A., Shevielov, D. V., Balashevskyi, A. S. (2013) Assessing the effectiveness of passive system of heat removal from the WWER containment under long-term blackout. Nuclear and Radiation Safety 2013, 2(58), pp. 19-23. (in Russian) (oai:dspace.nbuv.gov. ua:123456789/97457). 7. Petukhov, B. S., Genin, L. G., Kovalev, S. A. (1986) Heat transfer in nuclear power plants. Moscow: Energoatomizdat, 472. (in Russian).

8. Kirillov, P. L., Yuriev, Yu. S., Bobkov, V. P. (1990) Handbook of Thermohydraulic Calculations (nuclear reactors, heat exchangers, steam generators). Moscow: Energoatomizdat, 360. (in Russian). (ISBN 5-283-03829-7).

9. NUREG/CR-6519. (1997) Screening Reactor Steam/Water Piping Systems for Water Hammer. U.S. Nuclear Regulatory Commission. (ID Numbers Open Library OL15501865M).

10. PNAE Г-7-002-86. (1989) Strength Calculation Standards for Equipment and Pipelines of Nuclear Power Units. Moscow: Energoatomizdat, 525. (in Russian). (ID 61240*).

11. PNAE Г-5-006-87. (1989) Seismic Stability Design Standards for Nuclear Power Plants. Moscow: Energoatomizdat, 22. (in Russian). (http:// www. remgost.ru/vnp_doc/pnae-g-5-006-87-normy-proektirovanija-sejjsmostojjkikh-atomnykh-stantsijj/)

12. Korolyov, A. V., Derevianko, O. V. (2014) Emergency Makeup of Nuclear Steam Generators in Blackout Conditions. Nuclear and Radiation Safety, 2(62), 10-12. (in Russian).

13. Mazurenko, A., Skalozubov, V., Pirkovsky, D. et al. (2017) Analysis of applicability of the results of experimental researches of hydrodynamics to pump systems of thermal and nuclear energy installations. Nuclear Power and the Environment, 1(9), 19-21. (in Russian). (ISSN: 2311 - 8253).

Received 30 May 2019

Approved 02 July 2019

Available in Internet 05 September 2019 


\title{
Аналіз сучасних підходів підвищення ефективності в управлінні аваріями 3 втратою енергопостачання на ядерних енергоустановках
}

\author{
А. С. Денисова ${ }^{1}$, В. І. Скалозубов ${ }^{2}$ В. М. Спінов ${ }^{3}$, Д. В. Спінов ${ }^{4}$, Д. С. Пірковський ${ }^{5}$ Т. В. Габлая \\ $1,2,3,4,5,6$ Одеський національний політехнічний університет, пр-т Шевченка, 1, м. Одеса, 65044, Україна \\ $\triangle$ e-mail: ${ }^{5}$ pirkovskiy@opu.ua
}

У статті проведений аналіз підходів підвищення ефективності управління аваріями з повною втратою тривалого електропостачання з урахуванням уроків великої аварії на атомній станції Фукусіма-Дайічі у 2011 році. Показано, щз системи пасивного відводу тепла природною цииркуляцією через парогенератори не можуть забезпечити умови достатнього виконання функиій безпеки щодо відведення тепла від реактора і підтримки необхідного рівня живильної води в парогенераторі при аваріях з повною втратою тривалого електропостачання та множинних відмовах систем, важливих для безпеки. Впровадження альтернативних підходів із застосуванням аварійних живильних насосів 3 пароприводом від парогенератора вимагає додаткової розрахунково-експериментальної кваліфікації прачездатності/надійності в умовах аварії з повною втратою тривалого електропостачання та множинних відмовах систем, важливих для безпеки ядерної енергоустановки. Однак впровадження альтернативної системи SDEFP вимагає поглибленої кваліфікації за умовами аварій. Встановлено, що системи безпеки пасивного відведення тепла від парогенератора (адекватно електричним системам з активною безпекою) не можуть забезпечити функиії безпеки щэодо контролю необхідного рівня живильної води в парогенераторі та відведення тепла з ядра реактора під час аварій відключення (принаймні 72 години) та багатозабійності нещасні випадки. Зроблено висновок, що система парового насосного живильної води з парогенератором може бути альтернативним ріменням для забезпечення функиій безпеки при відведенні тепла через парогенератор під час аварій відключення. Додаткове дослідження ефективності роботи парових насосів на дослідних установках, щэо відповідають критеріям реальної життедіяльності гідродинамічної подібності, визнпчило необхідну умову для впровадження системи парового насосного живильного насоса. Таким чином застосування інтегрованого підходу до управління аваріями із відключенням є розумним. На початковій стадіі аварії з відносно високим тиском пари в парогенераторі потрібно подача живильної води паровим насосом.

Ключові слова: Ядерні енергоустановки; Аварія з втратою енергопостачання; Відведення тепла; Насоси з пароприводом

\section{Література}

1. IAEA International Fact Expert Mission of the Fukushima - Daiichi NPP Accident Following The Great East Japan Earthquake and Tsunami // IAEA Mission Report. - IAEA, 2011. - 160 p.

2. Анализ причин и последствий аварии на АЭС Fukushima как фактор предотвращения тяжелых аварий в корпусных реакторах: монография / В. И. Скалозубов, А. А. Ключников, В. Н. Ващенко, С. С. Яровой; под ред. В. И. Скалозубова; НАН Украины, Ин-т проблем безопасности АЭС. - Чернобыль (Киев. обл.): Ин-т проблем безопасности АЭС, 2012. $-280 \mathrm{c}$.

3. Комплекс методов переоценки безопасности атомной энергетики Украины с учетом уроков экологических катастроф в Чернобыле и Фукусиме: монография / В. И. Скалозубов, Г. А. Оборский, И. Л. Козлов и др.; ред.: В. И. Скалозубов; Одес. нац. политехн. ун-т, НАН Украины, Ин-т проблем безопасности атом. электростанций. Одесса: Астропринт, 2013. - 242 с.

4. Бахметьев А. М., Бабин В. А., Хизбуллин А. М. и др. Задачи расчетного экспериментального обоснования системы отвода остаточного тепла для атомных электростанций нового поколения. Тезисы докл. 5-й Международной научно-технической конференции «Обеспечение безопасности АЭС с ВВЭР», 29 мая - 1 июня 2007 г., Подольск. - Гидропресс, вып. 2, 303-308. ISBN 978-5-94883-074-2.

5. Наффаа Х. М., Дубковский В. А. Классификация пассивных систем удаления остаточного тепла 
из защитных оболочек реакторов. Одесский политехнический университет, Труды. - 2014. - Вып.1 (43). - C. 104-112. Doi: 10.15276 / op.1.43.2014.20.

6. Наффаa Х. М., Герлига В. А., Шевелев Д. В., Балашевский А. С. Оценка эффективности системы пассивного отвода тепла от защитной оболочки РУ с ВВЭР в условиях длительного обесточивания // Ядерная и радиационная безопасность. Киев, 2013. - Т. 2(58). - С. 19-23. (oai:dspace.nbuv. gov.ua:123456789/97457).

7. Петухов В. С., Генин Л. Г., Ковалев С. А. Теплообмен на атомных электростанциях. - М.: Энергоатомиздат, 1986. - 472 с.

8. Кириллов П. Л., Юрьев Ю. С., Бобков В. П. Справочник по теплогидравлическим расчетам (ядерные реакторы, теплообменники, парогенераторы). - М.: Энергоатомиздат, 1990. - 360 с. (ISBN 5-283-03829-7).

9. NUREG/CR-6519. Screening Reactor Steam/ Water Piping Systems for Water Hammer. U.S. Nuclear Regulatory Commission. - 1997. (ID Numbers Open Library OL15501865M).
10. ПНАЭ Г-7-002-86. Нормы расчета на прочность оборудования и трубопроводов атомных энергетических установок - М.: Энергоатомиздат, 1989. - 525 c. (ID $61240 *$ ).

11. ПНАЭ Г-7-006-87. Нормы проектирования сейсмостойких атомных станций. - М.: Энергоатомиздат, 1989. - 22 c. (http:// www. remgost.ru/ vnp_doc/pnae-g-5-006-87-normy-proek-tirovanijasejjsmostojjkikh-atomnykh-stantsijj/).

12. Королев А. В., Деревянко О. В. Аварийный состав парогенераторов в условиях отключения // Ядерная и радиационная безопасность. - Киев, 2014. - T. 2(62). - C. 10-12.

13. Мазуренко А. С., Скалозубов В. И., Пирковский Д. С. Анализ применимости результатов экспериментальных исследований гидродинамики к насосным системам тепловых и ядерных энергоустановок // Ядерная и радиационная безопасность. - Киев, 2014. - Т. 1(9). - С. 19-21. (ISSN: $2311-8253)$.

Отримана в редакції 30.05.2019, прийнята до друку 02.07.2019 